\title{
Konstruktivisme i naturvitenskapen: kunnskapssyn og didaktikk
}

\section{KONSTRUKTIVISMENS MANGE ANSIKTER}

Ordet konstruktivisme er blitt nærmest et moteord (noen vil kanskje si: slagord) i didaktisk forskning, spesielt innenfor naturfagenes didaktikk. Vi møter det ofte i faglitteraturen: i tidsskrifter, konferanserapporter, artikkelsamlinger og monografier - her finner vi stadig referanser til 'konstruktivistisk læring' og 'konstruktivistisk undervisning', det snakkes om 'den konstruktivistiske lærer', 'et konstruktivistisk vitenskapssyn', osv.

Men når vi tar et overblikk over denne litteraturen, blir det raskt klart at det finnes mange ulike 'konstruktivismer'! Med andre ord: Betegnelsen brukes i mange forskjellige betydninger, hvilket gjenspeiler de mange ulike innfallsvinkler man finner blant de som arbeider innenfor dette feltet. Faktisk er det slik at det ofte blir satt et beskrivende adjektiv foran, for å antyde hva slags konstruktivisme det handler om. I en artikkel (Geelan, 1997) er det listet opp ca. 20 eksempler fra aktuell faglitteratur: 'kognitiv konstruktivisme', 'kontekstuell konstruktivisme', 'dialektisk konstruktivisme', ... Og, for å komplisere bildet ytterligere: det er ikke allmenn enighet om bruken av disse adjektivene! For eksempel er det slik at den samme teorien kan bli beskrevet som 'kognitiv konstruktivisme', 'Piaget-konstruktivisme' og 'personlig konstruktivisme'.

Nå kan man selvsagt hevde at dette mangfoldet av ulike betydninger nettopp viser hvor kraftig og fruktbar konstruktivismen er som grunnleggende begrep i didaktikken. Men situasjonen er likevel problematisk: det er nemlig slik at flere av disse ulike konstruktivismeteoriene står i skarp motstrid med hverandre. Dette har ført til heftige, og tildels ganske hissige, diskusjoner i fagmiljøet - diskusjoner der deltakerne forsvarer "sin" variant av konstruktivisme, og/eller angriper andres. Og her kan temperaturen bli høy, med kraftuttrykk som "...pernicious nonsense..., "...hopeless relativism..." og "...save us ..(from) silliness...".

Jeg skal her i denne artikkelen ta for meg spesielt en variant kjent som radikal konstruktivisme. Jeg vil diskutere hvorfor den har vakt så mye rabalder i fagmiljøet, og argumentere for hvorfor jeg mener at nettopp denne varianten av konstruktivisme gir et godt epistemologisk fundament for undervisning i naturfagene. Men først, la oss se på begrepet 'konstruktivisme' i sin alminnelighet. Finnes det noe som alle de ulike konstruktivismeteoriene har felles? 
Det synes klart at enhver konstruktivisme nå baserer seg på følgende påstand:

(K) Læring er en aktiv prosess: eleven vil aktivt konstruere sin egen kunnskap i løpet av den læringsprosess han/hun gjennomgår.

(Her og i det følgende skal vi bruke ordet elev til å betegne, helt generelt, "en person som lærer noe" - på engelsk: a learner. Betegnelsen omfatter altså ikke bare skoleelever - den viser til en hvilken som helst person, uansett alder, som er i en læringssituasjon, enten dette skjer i en undervisningssammenheng eller "på egen hånd".) Som vi ser, er denne påstanden K, som vi kunne kalle "konstruktivismens basis", i utgangspunktet en hypotese om hvordan loering foregår. Men den har åpenbart også implikasjoner for undervisning (en aktivitet som prøver å styre, eller iallfall påvirke, elevens læring), kognisjon (elevens opplevelse/forståelse av den kunnskap som er blitt lært) og epistemologi (elevens kunnskapssyn, og lærerens).

Vi kan illustrere en del implikasjoner av utsagnet $\mathrm{K}$, ved å ta for oss et alternativ til dette utsagnet, en hypotese som ofte kalles:

(T) Læring er en passiv prosess: Informasjon "treffer" eleven, enten tilfeldig eller i en tilsiktet læringssituasjon; og den blir da tatt inn og lagret "i hjernen" et sted, uten videre behandling av eleven. Ved hjelp av hukommelsen kan da deler av denne informasjonen hentes frem fra lageret, og behandles videre i elevens sinn. (Vi har ikke noe godt norsk ord for det engelske "mind", som omfatter alle mentale prosesser i vår bevissthet og underbevissthet. Jeg har valgt å bruke ordet "sinn" her.)

I disse moderne tider er jo datamaskinen en naturlig metafor for en elev som lærer slik denne hypotesen $\mathrm{T}$ antar. Her har vi et operativsystem som håndterer innkommende data, finner ledig plass i det ytre lageret (harddisken), og lagrer dem der i den form de ble mottatt. Operativsystemet kan da hente lagrede data fra disken, for behandling i sentralenheten (prosessoren og internminnet), og lagre de behandlede dataene tilbake til disken igjen.

Denne metaforen trekker altså en analogi mellom elever og datamaskiner. Den antyder bl.a. at en aktiv lærer underviser ved å "sende inn data" til en passiv elev; og dermed vil læreren i stor utstrekning kunne kontrollere læringsprosessen - dvs. avgjøre hva eleven skal lære. Riktignok vil da elevene være ulike med hensyn til hvor effektivt deres operativsystemer kan lagre og hente data - med andre ord, noen vil ha "bedre hukommelse" enn andre. Og noen vil ha en kraftigere prosessor i sin sentralenhet, til å forstå og behandle data - dvs. de vil være "mer intelligente”...

Vi noterer at datamaskinmetaforen er, i en viss forstand, uhistorisk: Tidlig i det 20. århundre, da konstruktivistiske ideer først ble fremsatt seriøst som en modell for læring, var datamaskinen ikke der. Det naturlige transmissivistiske alternativet til disse ideene, uttrykt ved en metafor, ville da antakeligvis ha vært en eller annen versjon av Skinner's (1974) atferdsteori (behaviorismen), med sine mekanismer for "stimulus, respons og forsterkning".

Litt forenklet kan vi si at den konstruktivistiske hypotesen $\mathrm{K}$ hevder at vi mennesker ikke er datamaskiner - eller, i det minste, at vi ikke lærer (dvs. skaffer oss kunnskap) på samme måte som datamaskiner er programmert til å lagre og hente data! Og akkurat dette er neppe særlig kontroversielt: Det kan synes som om den konstruktivistiske hypotesen om læring er blitt noenlunde bredt akseptert - i alle fall i didaktiske fagmiljøer på universitets- og høgskolenivå. Faktisk er det slik at denne hypotesen alene ofte blir referert til som 'triviell konstruktivisme' - det minste felles grunnlag for alle konstruktivistiske teorier - og ordet 'triviell' antyder jo nettopp at den er "innlysende riktig" i en eller annen forstand..! Uansett, så er det vel få i dag som for alvor vil erklære seg som tilhenger av den transmissivistiske hypotesen $\mathrm{T}$. 
Og likevel: Vi kan spørre om denne aksepten av (den trivielle) konstruktivismen får konsekvenser for undervisning av ulike fag. Spesielt innenfor realfagene er det indikasjoner på at mange lærere fremdeles opererer innenfor det gamle transmissivistiske paradigmet - og at de finner god støtte for dette i datamaskinmetaforen. Denne metaforen kan virke svært tiltrekkende: datamaskiner er jo nettopp konstruert for å forsterke menneskets kapasitet for å behandle informasjon, og det kan da synes naturlig å anta at disse maskinene på en eller annen måte "reflekterer" den informasjonsbehandling som foregår i den menneskelige hjerne!

\section{OM BRUK AV METAFORER I DIDAKTIKKEN}

Dette illustrerer den viktige rollen som metaforer kan spille, i våre holdninger til de teoriene vi velger å tro på, eller forkaste. Så, la oss se nærmere på dette begrepet: hva en metafor er, hvilken funksjon den har, og hvordan den kan brukes i realfaglig didaktisk sammenheng. (For den som ønsker en mer detaljert analyse av metaforer og andre talemåter, slik de brukes i den vitenskapelige diskurs, anbefaler jeg å lese boken til Katz (1998).)

En metafor er per definisjon en deskriptiv analogi, som er formulert for å belyse et fenomen A, ved å trekke "assosiasjonslinjer" til et annet fenomen B som vi mener at vi forstår bedre. Det siste er vesentlig: metaforen er asymmetrisk, i den forstand at fenomenet A (som trenger å bli forklart) skal belyses ved å sammenlikne det med fenomenet B (som vi betrakter som allerede kjent/ forstått). Med andre ord: Noen (ikke alle) egenskaper ved B blir brukt til å belyse tilsvarende egenskaper ved A.

Metaforer kan ikke presses for langt: det er ikke slik at "A er av type B", dvs. at alle egenskapene til A kan gis en fullstendig forklaring ut fra tilsvarende egenskaper hos B. Et enkelt eksempel fra fysikken: Når elever starter med elektrisitetslære, blir de ofte invitert til å trekke paralleller mellom elektrisk ledningsstrøm og vannstrøm i et rør (se f.eks. Gentner \& Gentner, 1983 ). Disse parallellene illustrerer en del begreper fra elektrisiteten (spenning, strømstyrke) med tilsvarende begreper fra hydromekanikken (trykk, vannføring). Og dette kan fungere bra didaktisk, i den grad elevene har et mentalt bilde av hvordan vann strømmer i rør. Men etter hvert oppdager de jo en del situasjoner der metaforen "ikke bærer": det er f.eks. ikke slik at når en strømførende ledning blir kuttet, så vil elektronene i ledningen begynne å lekke ut i luften..! Likevel: metaforen beholdes i den didaktiske fremstillingen, som et nyttig verktøy til å anskueliggjøre noen (men slett ikke alle) sider ved fenomenet 'ledningsstrøm'. Tilsvarende "forklaringsteknikk", med bruk av metaforer, brukes nær sagt overalt i naturvitenskapen: elektronet illustreres som en liten kule, med feltlinjer som stråler inn mot kuleflaten, atomer er "små solsystemer" med elektroner i baner rundt kjernen, tyngdekraft forklares (i Newton's mekanikk) ved at legemer "tiltrekker hverandre" gjennom vakuum, eller (i relativitetsteorien) ved at de følger den "korteste banen" i et krumt tidrom, osv.

Metaforer gir oss altså et kraftig didaktisk verktøy, til å forklare/belyse/forstå de fenomener vi undersøker. Imidlertid er det også slik at en uheldig bruk av metaforer faktisk kan vanskeliggjøre forståelsen. Her er et par eksempler, hentet fra matematikken:

\section{Rasjonal vs. irrasjonal}

En begynnerelev i matematikk møter raskt begrepet rasjonale tall: dvs. tall som kan skrives som en brøk $a / b$, der $a$ og $b$ er hele tall, og $b$ ikke er lik null - og i forlengelse av dette, irrasjonale tall, som ikke kan uttrykkes på denne måten. (Ordet stammer opprinnelig fra det latinske ratio, som betyr 'fornuft', og også 'brøk'.) Nå er det slik at i moderne språkbruk (på norsk og mange andre europeiske språk) brukes ord som 'rasjonal/rasjonell' i betydningen "fornuftig" eller "rimelig", mens de motsatte 'irrasjonal/irrasjonell' har tilsvarende negativ betydning: "ufornuftig" eller "urimelig". Her blir jo denne metaforen svært lite relevant: fra et matematisk synspunkt er selvsagt ikke irrasjonale tall noe mindre "fornuftige" enn rasjonale. Likevel, i læringssituasjonen vil det ofte henge 
noe negativt ved irrasjonale tall: mange begynnere vil føle instinktivt at disse ikke er helt "til å stole på", så å si...

I denne situasjonen må da læreren (eller læreboka) inn, og forklare at det er historiske grunner til denne litt sære terminologien: Pytagoreerne hadde som mål, for mer enn to årtusener siden, å gi en fullstendig beskrivelse av naturen ved hjelp av brøker med heltallig teller og nevner. Det var derfor svært oppskakende for dem da man fant at visse veldefinerte og observerbare størrelser, som f.eks. diagonalen til et kvadrat med sidelengde lik 1, ikke kunne uttrykkes ved en slik brøk - og slike størrelser ble da betraktet som "mot fornuften", dvs. "irrasjonale" i den opprinnelige betydningen.

\section{Reell vs. imaginær}

La oss ta dette eksemplet et skritt videre. Rasjonale og irrasjonale tall danner til sammen mengden av reelle tall, som kan avbildes entydig i punkter på tallinjen. Dette er jo en betryggende metafor: de reelle tallene antas å beskrive 'virkeligheten' (engelsk: reality), altså, det som "finnes" og "kan observeres". De danner da også basis for differensial- og integralregningen, som i sin tur er grunnlaget for beskrivelsen av mange observasjoner i fysikken. Men nå blir utvidelsen til komplekse tall problematisk: slike tall har både en reell og en imagincer komponent, og den siste kan ofte bli oppfattet (av begynnereleven) som "uvirkelig", noe som bare hører hjemme i vår fantasi eller innbilning (engelsk: imagination), uten noe forbindelse med "den virkelige verden".

Igjen, dette er ikke noe problem i dagens matematiske tenkning: her ville man si at begge disse tallmengdene er, i en viss forstand, like "imaginære" (i betydningen "innbilte") - de er teoretiske begrepssystemer, med interessante matematiske egenskaper og (som det viser seg) nyttige anvendelser i fysikken. Og igjen, opprinnelsen til denne uegnede terminologien er historisk: den bastante motvilje blant matematikere (frem til det nittende århundre) mot å akseptere at det var mulig å diskutere noe så åpenbart mot all sunn fornuft som "kvadratroten av -1"!

Jeg vil hevde at disse "pedagogiske" problemene reflekterer noe mer enn bare "et uheldig valg av ord" - de illustrerer den avgjørende rollen som metaforer spiller, i å utvikle og forme vår læring. Metaforens funksjon i denne læringen kan, kort og noe forenklet, beskrives slik: Vi prøver å forstå et fenomen A ved å forbinde det med et annet fenomen B - som kan tilhøre en helt annen kategori enn A - slik at vi kan si at "A oppfører seg, eller virker, som B"... Metaforen er da en verbal beskrivelse av denne forbindelsen, som $v i$ har trukket mellom de to fenomenene: Dersom vi mener at vi forstår B, så vil denne beskrivelsen kunne gi oss en bedre forståelse av A også. Metaforen er altså en hjelp for vår kunnskapservervelse. Men vi ser at den også kan styre, dvs. legge føringer på, vår forståelse - og spesielt når den er kraftig: dvs. rik på assosiativ og/eller følelsesladet bildebruk!

I de matematiske eksemplene ovenfor består metaforene av emosjonelt ladede ordpar. Eleven inviteres til å se på tall som hørende til i motsatte kategorier med høy verdifaktor: rasjonale ("fornuftige") contra irrasjonale ("ufornuftige"), og reelle ("virkelige") contra imaginære ("innbilte"). Som allerede nevnt, er disse metaforene irrelevante i matematikken. Likevel: de blir beholdt i språkbruken, og de kan da virke negativt inn på læringen, hvilket mange matematikklærere kan bevitne. Spesielt gjelder dette når man skal lære om bruken av komplekse tall i fysikken - man kan oppleve at elever spør: "hva er det som virkelig måles av et imaginært tall", eller "hva er det disse tallene beskriver $i$ virkeligheten"..?

Og nettopp denne stadige appellen til "virkeligheten", som basis for den kunnskap vi kan få om naturen, er en meget vesentlig faktor i den pågående debatt om konstruktivismen, som vi snart skal se: mye av temperaturen i denne debatten skyldes nettopp en uheldig bruk av bestemte metaforer, spesielt innenfor naturfagenes didaktikk. 
La oss nå se nærmere på begrepet sannhet (med sine mange sidebetydninger av 'å være korrekt', 'å være riktig, 'å beskrive virkeligheten', osv.), slik vi finner den i naturvitenskapelig språkbruk. Hvor stammer dette begrepet fra - hva handler det om? Jeg vil hevde at det har "innvandret", så å si, til naturvitenskapen fra to helt andre områder: (i) dagliglivet, og (ii) jussen. Dette er diskutert i detalj annensteds (Quale, 2002) - la meg bare her kort oppsummere de viktigste punktene:

I dagligtale viser ordet 'sannhet' vanligvis til en beskrivelse av 'det som virkelig skjedde', eller 'sakens fakta': vi sier at "hun snakker sant" eller at "dette er en sann historie". Legg merke til at denne språkbruken har sterke moralske overtoner: det motsatte av sannhet er gjerne 'løgn', eller 'forbannet dikt'..! Så, her har vi et nytt eksempel på et emosjonelt ladet ordpar: sant (godt, riktig, ærlig,...) contra usant (løgnaktig, feil, uærlig,...). Tilsvarende har vi i logikk (og i programmeringsspråk) ordparet True/False, som betegner sannhetsverdi av utsagn - men da uten noen moralsk verdiladning.

Den samme språkbruken finner vi i jussen. Dennes oppgave - slik det oppleves av vanlige folk, som ikke har juridisk utdannelse - er å regulere samhandling mellom mennesker i samfunnet, ved å etablere og håndheve lover (regler) som skal følges; her ser vi opprinnelsen til talemåter som "å få lov til", "med loven i hånd", osv. Også i juridisk sammenheng er det ofte behov for å "finne sannheten" i en eller annen konkret situasjon - politi-etterforskning, rettssak - for å kunne anvende loven på korrekt måte. Og den stilltiende antakelsen er da at denne sannheten faktisk finnes: dvs. at det alltid er mulig å "finne fakta" i det tilfellet som behandles.

Poenget er nå at en tilsvarende språkbruk også finnes i naturvitenskapen, og at den stammer (vil jeg hevde) nettopp fra de områdene som er omtalt ovenfor. Språkbruken i naturvitenskapen er faktisk ganske lik den vi finner på det rettslige området: naturen beskrives ved hjelp av jussen, med sannhetsbegrepet som metafor! Man snakker om (natur)lover, som regulerer fenomener og prosesser i naturen. En billedbruk vi ofte finner, f.eks. hos Newton, er med Gud som en slags "overdommer" som har definert de (natur)lovene som verden må adlyde! En forskjell er da at rettslige lover kan brytes (av mennesker som setter seg utenfor loven), mens naturlover ikke kan det (om vi da ikke anerkjenner fenomenet "mirakel" - dvs. en guddommelig inngripen, der naturlovene settes ut av kraft). Dermed er det lite behov i naturvitenskapen for noe som svarer til en "rettssak", der man skal overbevise en jury om skyld eller uskyld! Tvert imot: en etterforskning/ undersøkelse av det foreliggende bevismateriale (ved observasjon og teoretiske overveielser) vil til slutt alltid lede oss frem til de riktige naturlovene, som gjelder i den aktuelle situasjonen - og dermed avsløre sannheten, både om "det som har skjedd" (retrodiksjon) og om "det som vil skje" (prediksjon).

Denne analogien mellom naturvitenskap og jus er selvsagt nokså forenklet. Den er satt noe på spissen her, for å illustrere hvilken rolle en metafor som 'sannhet' kan spille når det gjelder å legge føringer på våre tanker om naturvitenskapen. Spesielt vil denne metaforen, som vi nå skal se, favorisere et kunnskapssyn preget av vitenskapelig realisme, og dermed motarbeide et mer konstruktivistisk inspirert kunnskapssyn.

\section{OM SANNHET OG VIRKELIGHET - DEN RADIKALE KONSTRUKTIVISMEN}

Som vist ovenfor, kan datamaskinmetaforen brukes til å illustrere et transmissivistisk syn på hvordan elever lærer. Denne metaforen er jo ganske besnærende: vi inviteres til å forstå læringsprosessen (en kompleks aktivitet i den menneskelige hjerne) ut fra virkemåten til en datamaskin (som vi kanskje føler at vi forstår bedre). Og selv om vi ikke har denne oppfatningen av læring, og støtter et mer konstruktivistisk syn, kan datamaskinmetaforen fremdeles være nyttig, til å illustrere "hva læring ikke er". 
Så, la oss nå se på konstruktivismen: hva slags metaforer er det som er aktuelle her? Som vi har sett, er ikke den trivielle konstruktivismen (basert på påstanden $K$, se avsnitt 1) alene å oppfatte som en fullstendig teori for læring: det er heller slik at den danner basis for en rekke innbyrdes motstridende oppfatninger av konstruktivisme. Her vil jeg diskutere den teorien som kalles $\mathrm{ra}$ dikal konstruktivisme, opprinnelig fremsatt av Ernst von Glasersfeld (1978, 1984, 1989, 1995, se også Foerster \& Glasersfeld, 1999)), og spesielt dens innvirkning på epistemologien (kunnskapssynet) i naturfagenes didaktikk. Denne teorien er blitt ganske kontroversiell, og er gjenstand for tildels hissige debatter i faglitteraturen, som allerede nevnt. Så, la meg presisere her og nå at jeg $i k k e$ ønsker å argumentere for at den radikale konstruktivismen er "riktig" eller "korrekt" - tvert imot, så følger det av teorien selv at metaforer som "å være riktig" er irrelevante i naturvitenskapens epistemologi.

Von Glasersfeld (1995, p.51) definerer radikal konstruktivisme ved hjelp av to påstander, her gjengitt i noe forkortet form (min oversettelse):

R1: Kunnskap mottas ikke passivt, men bygges aktivt opp av eleven (den som erverver seg kunnskapen)

R2: Kunnskap erverves som en tilpassing; dens funksjon er å organisere elevens opplevelsesverden, ikke å oppdage en objektivt eksisterende virkelighet

Vi gjenkjenner R1 som en versjon av den trivielle konstruktivismen, idet den definerer kunnskap som "produktet av aktiv læring". Men R2 er kontroversiell: Ved første øyekast synes den å hevde at vi ikke kan lære noe om "den virkelige verden"..! Er ikke dette et angrep på selve grunnlaget for all naturvitenskap?

I utgangspunktet kan vi jo notere at den radikale konstruktivismen faktisk er blitt brukt som grunnlag for diskusjon omkring didaktiske spørsmål i realfag - f. eks. i fysikk (Glasersfeld 1992), og også i matematikk (Glasersfeld 1991). Disse diskusjonene var i hovedsak fokusert på undervisning og læring. Her vil jeg ta opp mer direkte spørsmålet om naturvitenskapens epistemologi: Hva kan den radikale konstruktivismen si om vår kunnskap på det naturvitenskapelige området, og hvorfor har dette skapt slikt oppstyr? Dette kontroversielle aspektet kommer klart frem, når vi leser artiklene i tidsskriftet Science \& Education, 6 (1997), No.1-2 (et spesialnummer om konstruktivisme i naturvitenskapens didaktikk): de synspunktene som uttrykkes her spenner fra 'svært negative' (Ogborn 1997, Nola 1997), over 'mer eller mindre kritiske' (Bickhard 1997, Matthews 1997), til 'meget positive' (Hardy \& Taylor 1997). Og det er, vel å merke, den samme teorien - radikal konstruktivisme - som behandles av alle disse! Og denne diskusjonen fortsetter - se f.eks. Larochelle (1998), og Phillips (2000).

Nettopp dette veldige spennet i synspunkter og innfallsvinkler på den radikale konstruktivismen reiser et viktig prinsipielt spørsmål: Har det noen mening å spørre hvilken av disse mange ulike tolkningene som er "den korrekte": dvs. gir en "sann fremstilling" av teorien, slik den er definert av von Glasersfeld? Mitt svar, som vil bli begrunnet her, er at: (i) dette er, i et radikal-konstruktivistisk perspektiv, ikke et meningsfylt spørsmål; og (ii) det er metaforen 'sannhet' som ligger til grunn for disse kontroversene.

La oss se nærmere på den radikale konstruktivismens "2. lov", påstanden R2. Her er det viktig å være klar over at teorien behandler kunnskap og loering konsekvent som et "gjensidig definerende" ord-par: litt forenklet kan vi si at "læring er den aktivitet som leder til kunnskap, kunnskap er resultatet av aktiv læring”. Vårt sinn kan (og vil) selvsagt inneholde andre ting: tro, følelser, vilje, personlige preferanser... men disse er da ikke å betrakte som kunnskap, de er ikke et resultat av læring! 
Teorien trekker et skarpt skille mellom epistemologi (spørsmålet om kunnskapens natur) og ontologi (spørsmålet om det eksisterer en "objektiv virkelighet", uavhengig av vår opplevelse). Den påstår ikke at en slik objektiv virkelighet ikke eksisterer; men den hevder at dette (spørsmålet om en slik virkelighet eksisterer) ikke hører inn under begrepet 'kunnskap' - det er noe som ikke kan læres! I radikal konstruktivisme betraktes kunnskap som en modell, eller struktur, som vi legger på vår opplevelse av (en del av) verden, for bedre å kunne tilpasse oss den. Spesielt betraktes naturvitenskapen som en slik modell - definert ved et sett av teorier, metoder, prosedyrer og verktøy - som kan brukes til å strukturere en bestemt undermengde av våre opplevelser: nemlig de fenomener som til enhver tid blir ansett å være legitim gjenstand for naturvitenskapelig forskning.

Dette betyr ikke (slik det ofte blir hevdet) at radikal konstruktivisme nødvendigvis må lede til den ekstreme relativismen som kalles solipsisme: den oppfatning at enhver kan konstruere sin egen verden, slik han/hun ønsker at den skal være! Tvert imot, denne teorien aksepterer som en kjensgjerning at mennesker deler en felles opplevelsesverden - hvis ikke, ville det ikke vært mulig for oss å kommunisere med hverandre - og at det er naturlig for oss å prøve å etablere felles kunnskapsbaser som kan fremme utveksling og samarbeid for å oppnå felles mål. Naturvitenskapen er nettopp en slik felles kunnskapsbase, som åpenbart har hatt stor suksess i å levere svar på de spørsmål vi har stilt den. Men poenget er at denne kunnskapsbasen, uansett suksess, beskriver ikke (og kan ikke beskrive) noen "objektiv virkelighet" - ikke fordi kunnskapsbasen er mangelfull, men fordi et slikt begrep ikke faller innenfor det som vi kan lære noe om! Sagt på en annen måte: fra et radikal-konstruktivistisk perspektiv kan et begrep som "virkeligheten", eller "den virkelige verden", ikke bety noe mer enn det fenomenologiske "alt som det er mulig for oss å oppleve" - eller, slik Wittgenstein sier det: "Verden er alt som er tilfelle" (den berømte første setning i Wittgenstein's Tractatus, 1921)!

Dette kunnskapssynet, slik det er beskrevet ovenfor, blir ofte betegnet som vitenskapelig relativisme. (Legg merke til at dette er en ganske bred kategori, som også inkluderer mange andre typer av konstruktivisme som er nokså forskjellige fra den som diskuteres her.) Etter denne klassifikasjonen blir det motsatte syn (som også finnes i mange ulike varianter) gjerne betegnet som vitenskapelig realisme: teorier med et slikt utgangspunkt inneholder som regel en antakelse om at det finnes en objektiv virkelighet, uavhengig av menneskelig opplevelse, $\underline{o g}$ at det er mulig for naturvitenskapen å komme frem til "sann kunnskap" om denne virkeligheten. Denne siste betingelsen er viktig: Man kan selvsagt innta det standpunkt at det finnes en objektiv ytre virkelighet, men at det ikke er mulig for oss å oppnå sann kunnskap om den. Dette ville da være en variant av vitenskapelig relativisme, slik dette er definert ovenfor: en slik virkelighet er bare et synonym for det den radikale konstruktivismen kaller "vår felles opplevelsesverden"!

Hvorfor har så den radikale konstruktivismen fremprovosert slik motstand? Tross alt, så synes det å være lite kontroversielt å si at: (i) vi kan bare oppnå kunnskap om verden gjennom vår persepsjon (oppfatningsevne); og (ii) vi søker slik kunnskap for å kunne bruke den til våre egne formål: å bedre kunne forstå og beherske vår egen verden? Her må skytes inn at ordet 'persepsjon' står for vår totale evne til å oppfatte verden omkring oss. Dette omfatter ikke bare mottak av sanseinntrykk, men også vår refleksjon over slike inntrykk! Det siste er en komplisert prosess - eller kanskje snarere et sett av kompliserte prosesser - som utgjør det vi kunne kalle elevens "databehandling" av input fra verden. Her inngår forventning og sosial betinging (vi oppfatter det vi venter å oppfatte), hukommelse (plassering av hendelser og objekter i tid og rom), abstraksjon og generalisering, søken etter årsak/virkningssammenhenger, og mye annet. Å gå nærmere inn på disse prosessene ville sprenge rammene for denne artikkelen; men la det i alle fall være klart at radikal konstruktivisme er noe langt mer enn det vi kaller "naiv positivisme": den oppfatning at sanseinntrykk alene kan gi oss en fullstendig forståelse av verden! 
Jeg vil hevde at kontroversen omkring radikal konstruktivisme iallfall delvis skyldes en utbredt bruk av metaforer som 'sannhet' og 'virkelighet', i diskusjonen omkring naturvitenskapenes epistemologi. Disse metaforene understøtter den antakelse at en vitenskapelig teori kan være "korrekt", i den betydning at den gir en sann eller riktig beskrivelse av "den virkelige verden"; og at vitenskapens oppgave er å søke etter slike "sanne teorier" - dvs. teorier som angir naturlovene på en korrekt måte. La oss se på dette.

\section{OM VITENSKAPELIGE TEORIER}

Rent logisk har vi at en sann teori må være unik: det kan ikke finnes innbyrdes motstridende sanne teorier for det samme fenomen-område. (Derimot kan en teori ha ulike formuleringer: i forskjellige "språk", så å si. Et klassisk eksempel finner vi i kvantefysikkens tidlige historie, der to tilsynelatende ulike teorier: Schrödingers bølgemekanikk og Heisenbergs matrisemekanikk, senere ble vist å være ekvivalente formuleringer av samme teori.)

Videre følger det at de sanne teoriene må "eksistere der ute", i en eller annen forstand, slik at de kan oppdages dersom vi leter "på riktig sted". Med andre ord: naturvitenskapelig forskning blir en slags "oppdagelsesreise", eller "skattejakt". Og, når skatten først er funnet, så kan den jo ikke finnes en gang til...!

I dette perspektivet kan man se på den forskningsinnsats som har vært gjort i de senere år, for å finne "den endelige teorien" (engelsk: The Final Theory) i fysikken, se f.eks. boken til Steven Weinberg (1993). Målet er å fullføre den utvikling med "enhetliggjøring" som ble påbegynt i det 19.århundre, der tilsynelatende ulike fenomener ble brakt "inn under samme paraply", og dermed fremkomme som ulike aspekter av det samme fenomenet. F.eks. ble det tidlig demonstrert at elektrisitet og magnetisme kunne betraktes som ulike aspekter av en mer komplisert størrelse: det elektromagnetiske felt. Senere har også andre fenomener (svake og sterke kjernekrefter) blitt trukket inn under den samme paraplyen; og tankegangen er nå at dette skal være mulig å få til for alle fysiske vekselvirkninger - en realisering av Albert Einsteins gamle drøm om en enhetlig feltteori. Med andre ord: Det skal være mulig å finne en "slutt-teori", som ofte blir referert til i litteraturen som TOE (engelsk: Theory Of Everything) - et sett likninger som bestemmer og styrer et "superfelt" som forener alle de krefter, partikler, osv. som utgjør den fysiske verden! (Dette er jo en storslagen visjon - og den gjelder ikke bare for fysikken! Det er ikke uvanlig, blant fysikere i alle fall, å anta at alle andre disipliner i naturvitenskapen til syvende og sist bare omhandler fenomener som er fullstendig styrt av fysiske lover: dette gjelder for kjemien, geologien,... ja, til og med for biologien. Eller, sagt på en annen måte: all naturvitenskap er egentlig fysikk! Denne "fysikkens imperialisme", uttrykt ved utsagn som "det dere kjemikere, biologer, osv. driver med, er jo egentlig ikke noe annet enn en del av fysikken..!", har opp gjennom årene provosert mange naturvitere.)

Men om man nå skulle finne denne endelige teorien, hva så? Har vi da nådd frem til slutten på naturvitenskapelig forskning? Dette diskuteres faktisk helt seriøst blant fysikere og andre naturvitere - jf. John Horgans bok The End of Science (1996). Tross alt, når noe ligger der og venter på å bli oppdaget, så kan det jo ikke oppdages mer enn én gang..!? Horgan trekker dette et godt stykke videre og diskuterer en mulig slutt, ikke bare for fysikken, men også for andre vitenskaper: biologi, informatikk, sosiologi,... Nå bør man huske at tilsvarende "endetidsvisjoner" også ble fremført mot slutten av 1800-tallet. Da anså mange at alle interessante problemer innenfor fysikken var brakt under kontroll, med Newtons mekanikk og Maxwells elektromagnetisme - teorien var nå på plass, og det gjensto bare å måle fysiske størrelser med stadig større nøyaktighet. Og dette var bare noen få år før relativitetsteorien og kvantemekanikken kom på banen, og revolusjonerte hele naturvitenskapen..! 
Og hva har så den radikale konstruktivismen å si, om slike perspektiver og problemer? Det sentrale spørsmålet her kan stilles slik: Er en vitenskapelig teori noe som blir oppdaget, eller noe som blir konstruert av oss? Jon Ogborn diskuterer dette i en artikkel (1997) - som er svært kritisk til radikal konstruktivisme - der han setter metaforene 'å finne' og ‘å lage’ opp mot hverandre. Ogborn argumenterer for at begge disse er gyldige i naturvitenskapelig teoribygging: Vitenskapens mål er å finne frem til korrekt kunnskap om verden; men siden våre observasjoner ofte er unøyaktige, er det mye rom for å lage ulike teorier som reflekterer denne kunnskapen. I motsetning til dette hevder den radikale konstruktivismen at teorier er (og må være) laget (konstruert), ikke funnet - men da på en slik måte at de "passer inn" med vår persepsjon: både sanseobservasjoner og refleksjoner. Og en slik konstruksjon kan da gjøres på mange ulike måter, siden vitenskapelige teorier i så stor grad er underdeterminert av observasjoner!

I von Glasersfelds terminologi kan en vitenskapelig teori ikke være "sann" eller "usann", men bare mer eller mindre levedyktig (engelsk: viable). Dette er jo en metafor fra biologien, som beskriver en organismes evne til å leve i likevekt med sitt miljø. Og denne likevekten, for teorier som for levende organismer, er noe som kan forandre seg! For å bli i metaforen: Det kan komme til nye observasjoner, som er i konflikt med teoretiske prediksjoner; og dette vil skape et behov for å endre teorien (en utvikling av organismen), eventuelt lage en ny teori og droppe den forrige (la den gamle organismen dø). Eller det kan skje et "klimaskifte", som tvinger frem en forandring av teorien (organismen). Følgende eksempel kan belyse dette:

Vi kjenner fra skolen den geosentriske (jordsentrerte) modell for himmellegemenes bevegelser: solen, månen, planetene og stjernene går i sirkler rundt jorden, som ligger stille i sentrum. (Disse bevegelsene er faktisk ikke perfekte sirkler: for å få modellen til å passe med observasjoner innførte man en antakelse om at noen legemer beveget seg i såkalte episykler, dvs. i sirkel rundt et punkt som så i sin tur gikk i sirkel rundt jorden.) Denne modellen, som ble fremsatt for rundt to tusen år siden, ligger til grunn for det middelalderske verdensbilde: det lukkede univers som vi kan lese om i f.eks. Dantes verk Den guddommelige komedie. Og den har, helt frem til de siste tiår, dannet grunnlaget for bl.a. navigasjon: Nitide observasjoner av himmellegemenes posisjoner i forhold til jordoverflaten var nedtegnet i store tabeller; og disse ble brukt, sammen med observasjon av solhøyde og tid, til å bestemme et skips posisjon på havet. (Nå er det mer vanlig at skipene bestemmer sin posisjon ved hjelp av satellittnavigasjon - men også disse satellittene kan vi si bruker den geosentriske modellen, for så vidt som de beregner posisjoner relativt til en stasjonær jordoverflate.)

I motsetning til dette har vi den heliosentriske (solsentrerte) modell, der solen ligger i sentrum og roterer der, mens planetene (inkludert jorden) roterer om en akse og beveger seg i elliptiske baner rundt solen, og månen beveger seg i bane rundt jorden. I denne modellen ligger stjernene mer eller mindre fast: deres tilsynelatende bevegelse på nattehimmelen skyldes jorden egenrotasjon.

Vi har alle lært at den heliosentriske modellen er den "riktige" - det er jorden som går rundt solen, og ikke omvendt!!! Men det kan være interessant å spørre: Hva er det som gjør denne modellen "riktig"?

Det er jo faktisk sant at solen (og de andre himmellegemene) går rundt jorden, når de observeres i et koordinatsystem som er i ro i forhold til jordoverflaten. Og i moderne fysikk er det anerkjent at valget av koordinater for å beskrive et gitt fysisk system er vilkårlig - det finnes i prinsippet ikke noe koordinatsystem som er "riktigere" enn noe annet. Derimot vil det, i konkrete situasjoner, ofte være slik at noen koordinatsystemer viser seg å være mer hensiktsmessige å bruke enn andre. Og dette er jo nettopp tilfellet for den geosentriske modellen: den gir (i sfæriske polarkoordinater) en 
god beskrivelse av himmellegemenes vinkelposisjoner (sett fra jordoverflaten) til enhver tid; og disse dataene kan bruke til navigasjon, som nevnt ovenfor. Ingen ville noen gang falle på tanken om å bruke den heliosentriske modellen til navigasjon på havet - dette er i prinsippet mulig, men ville bli uoverkommelig komplisert! På den annen side: dersom vi ønsker å studere banen til planeten Mars, så vil denne få en mye enklere matematisk form i den heliosentriske modellen (en ellipse) enn i den geosentriske (en kurve med en matematisk meget komplisert variasjon, både av radiale og angulære koordinater).

Det kan altså se ut som den geosentriske modellen passer best i noen sammenhenger, og den heliosentriske i andre. Og likevel: Vi "vet" alle at den heliosentriske modellen er riktigere enn den geosentriske. Men hvorfor er den det? Som vi så, er det ikke fordi den stemmer bedre overens med observasjoner! Svaret er at det har skjedd et "klimaskifte" - eller kall det gjerne et paradigmeskifte - i fysikken: Nå stiller vi andre spørsmål, og krever andre forklaringskategorier, enn det man gjorde før.

Den geosentriske modellen har sine røtter i gresk filosofi i antikken. Her ble sirkelen ansett å være mer "perfekt" enn andre kurveformer; og siden himmellegemene nærmest per definisjon var å betrakte som perfekte, dvs. ubesudlet av vår jordiske verden, var det da åpenbart at de måtte bevege seg i sirkelbaner. For å få overensstemmelse med observasjon, måtte man etter hvert komplisere bildet ved å innføre episykler - sirkler inni sirkler - som nevnt. Man tenkte seg at himmellegemene var festet til gjennomsiktige kuleskall (en perfekt geometrisk form!), som holdt dem på plass i banen mens skallets roterte; men utover dette var det ingen spørsmål om årsaken til denne sirkelbevegelsen (man mente kanskje at det som er perfekt trenger ingen videre forklaring..?!).

Den heliosentriske modellen blir ofte forbundet med Kopernikus, men man kan vel si at den oppnådde sitt hegemoni i naturvitenskapen først med Newton's store verk Principia. Her er det ikke lenger snakk om perfekte former. Bevegelsene tilskrives nå en fysisk årsak, beskrevet ved Newtons gravitasjonslov; massene trekker på hverandre og beveger seg i bane rundt sitt felles tyngdepunkt. I vårt solsystem er det solen som inneholder det aller meste av massen. Dermed vil tyngdepunket til enhver tid ligge nær solens sentrum; og baneformen kan da utledes å være, med god tilnærmelse, ellipser med solen i det ene brennpunktet (Kepler's 1.lov).

Her ser vi grunnen til at den heliosentriske modellen anses å være "bedre" enn den geosentriske i fysikken: Det har vært et skifte i synet på hva slags forklaringskategorier som skal brukes. Vi ønsker nå å basere våre forklaringer av observerte bevegelser på ideen om en fysisk vekselvirkning (en årsak/virkningssammenheng, her gitt ved Newton's gravitasjonslov), ikke på en estetisk ide om hva som er den "perfekte baneform". Den geosentriske modellen blir da stående igjen, ikke som "feilaktig" (den er i overensstemmelse med observasjon, som nevnt foran, og faktisk fremdeles hensiktsmessig å bruke til en del praktiske formål), men mer som irrelevant i fysikken: den tilbyr ikke den type forklaring som vi etterspør!

Nå har jo den heliosentriske modellen lidd en tilsvarende skjebne. I kosmologien betraktes ikke lenger solen som "verdens sentrum" - tvert imot, den er forvist til en beskjeden plassering langt ute $\mathrm{i}$ en av spiralarmene i vår galakse. (Faktisk er det slik at verden ikke lenger antas å ha noe sentrum..!) Og den fysiske forklaring av gravitasjon i Newtons mekanikk, som et resultat av gjensidige tiltrekningskrefter mellom masser, er erstattet i Einsteins generelle relativitetsteori av en geometrisk forklaring: en masse beveger seg alltid langs den "korteste vei mellom to punkter i banen", men denne bevegelsen skjer i et tidrom som er krummet av andre masser i nærheten. Og, nok en gang: dette betyr ikke at Newton's mekanikk er "feilaktig"! Tvert imot, den stemmer godt overens med observasjon innenfor sitt gyldighetsområde, og er den mest hensiktsmessige å bruke til navigasjon for nåtidens romfart (innenfor vårt solsystem). Men i andre sammenhenger, spesielt innenfor kosmologi og astrofysikk, er Einsteins forklaringsmåte mer egnet. 
La oss nå gå tilbake til de to kunnskapssyn: realisme og relativisme, som settes opp mot hverandre i debatten omkring konstruktivismen. Det første hevder at det eksisterer en objektiv virkelighet, som er uavhengig av menneskelig persepsjon, og at det er mulig for naturvitenskapen å komme frem til sann kunnskap om denne virkeligheten. Dette realistiske synet støttes av metaforen 'sannhet', som allerede nevnt. Faktisk har denne metaforen en slik "styrende kraft" på våre tanker at nettopp det realistiske kunnskapssynet kan virke "innlysende" eller "en følge av sunn fornuft"! (Man kan da ikke være motstander av sannheten..? Hvem vil erklære seg som urealistisk..?) Og da blir jo et relativistisk syn, slik man finner i den radikale konstruktivismen, tilsvarende "absurd" og "mot sunn fornuft"..!

I motsetning til dette har vi det radikal-konstruktivistiske kunnskapssynet, som går skarpt ut mot "den tusenårige realistiske tradisjon, med målet å oppnå objektiv kunnskap ", i von Glasersfeld's ord (1995, p.25). Von Glasersfeld hevder at en slik objektiv virkelighet nødvendigvis må ligge utenfor rekkevidde av vitenskapelig kunnskap (slik denne kan oppnås gjennom læring), og dermed kun blir et spørsmål om personlig tro eller preferanse. En vitenskapelig teori er noe vi lager (konstruerer) for å legge en struktur på bestemte fenomener i vår opplevelsesverden, og dermed oppnå bedre forståelse av (eller kontroll over) disse fenomenene. I en biologisk inspirert metafor: Slike teorier må være levedyktige: dvs. stemme rimelig bra med observasjoner, og ellers tilfredsstille de ulike forklaringsmodeller vi pålegger den (f.eks. krav om matematisk konsistens). Og de vil ofte utvikle seg mot, eller bli erstattet av, nye teorier som er "bedre", i den forstand at de kan organisere fenomenene på en måte vi synes er mer tilfredstillende. Men det har ikke mening å si at de nye teoriene er "riktigere", eller at de "ligger nærmere sannheten": Vi har ingen måte å avgjøre hva denne sannheten er, eller hvor langt vi er fra den!

La meg kort oppsummere det jeg ser som essensen i radikal konstruktivisme, når det gjelder kunnskapssyn: Det finnes ingen "sanne" eller "riktige" vitenskapelige teorier der ute, som venter på å bli oppdaget - like lite som det finnes "sann tro" eller "riktig musikkforståelse"! Faktisk er det slik at i lys av radikal konstruktivisme vil heller ikke denne teorien selv kunne hevde å være "sann" eller "riktig": det er mer korrekt å si at den "tilbyr seg selv" som en kunnskapsteoretisk plattform, som kan tas i bruk av den som måtte føle at dette er en fruktbar måte å betrakte naturvitenskapen på. Denne "agnostiske" holdningen står selvsagt i fundamental motsetning til den vitenskapelige realismen, som jo hevder at den representerer det riktige kunnskapssynet..!

\section{KONSEKVENSER FOR DIDAKTIKKEN}

Så kan man spørre: Hvilken betydning kan denne filosofiske diskusjonen omkring ulike kunnskapssyn ha for naturvitenskapens didaktikk: f.eks. for undervisningen i naturfagene i skolen? Faktisk blir det ofte hevdet (Grandy 1997) at lærerne ikke trenger bry seg om dette - de bør "ta seg av undervisningen, og overlate filosofien til filosofene"! Men jeg vil hevde at dette ikke er mulig: Det å undervise vil si å prøve å formidle til elevene en bestemt type kunnskap, og når man gjør dette kan man ikke unngå å samtidig formidle et bilde av hva denne kunnskapen "betyr". Med andre ord: læreren vil nødvendigvis bidra til at elevene får en eller annen forestilling om 'naturvitenskapens vesen' (engelsk: the nature of science), enten han/hun er klar over dette eller ikke. Og det finnes undersøkelser (se f.eks. Alters 1997 ) som indikerer at lærere i naturvitenskapelige fag har svært ulike holdninger nettopp til hva som er naturvitenskapens vesen.

I motsetning til dette vil jeg hevde at det er av stor viktighet i dag, nettopp i naturfagenes didaktikk, å tenke nøye over hvilket kunnskapssyn man ønsker å formidle. Vi ser i dag (kanskje mest tydelig i de utviklede landene) en del holdninger til naturvitenskap og teknologi som er foruroligende. Problemet kan kort oppsummeres slik: På den ene side fungerer det moderne samfunn på et høyt teknologisk nivå, og vedlikeholdet av denne teknologien krever stadig ny tilførsel av høyt kvalifisert arbeidskraft. På den annen side synes det å være en dalende interesse blant skoleelever for å 
lære om naturvitenskap og teknologi, med et tilsvarende fall i rekrutteringen til realfagene i skolen - hvilket da selvsagt leder til et tilsvarende fall i produksjonen av slik kvalifisert arbeidskraft på universitets- og høgskolenivå. Men legg merke til at dette ikke nødvendigvis skyldes manglende interesse for produktene av høyteknologien. Faktisk viser undersøkelser (se f.eks. Sjøberg 1998) at det er en positiv interesse for vitenskapelige og teknologiske problemstillinger blant publikum i dag, og et godt marked for f.eks. populærvitenskap i magasiner og andre media. Og det er velkjent at norsk ungdom ligger langt fremme i bruk av datamaskiner, mobiltelefoner, musikkmaskiner og annet - men det kan se ut som de ikke ønsker å lære om denne teknologien, bare å bruke den!

Her ser vi en internasjonal tendens, ofte beskrevet i litteraturen (Sjøberg 1997, Jenkins 1997) som et symptom på manglende 'naturvitenskapelig allmenndannelse' (engelsk: scientific and technological literacy). Denne mangelen viser seg hos mange på iallfall to måter: (i) likegyldighet, eller til og med mistillit, mot vitenskap og teknologi; og (ii) en økende interesse for ulike typer pseudovitenskap eller "anti-vitenskap", som f.eks. astrologi, healing, kreasjonisme,...

Enkelt sagt: Man kan se en tendens, spesielt blant unge mennesker, til å avvise naturvitenskap som lite attraktivt. Og flere undersøkelser (se Sjøberg 2000, og referanser der) indikerer at i hvert fall en av årsakene til denne avvisningen kan være det bildet av vitenskapen som formidles i mye av undervisningen i realfagene: naturen beskrives i form av en kald, hard og upersonlig "objektiv virkelighet", styrt av allmenngyldige og uforanderlige lover som er helt uavhengige av (og irrelevante for) de spørsmål og problemer som er viktige for mennesker i deres liv. Det er ikke urimelig å anta at nettopp en slik realistisk epistemologi kan bidra vesentlig til å støte mange bort fra naturvitenskapen!

Her mener jeg at den radikale konstruktivismen kan tilby et mye mer attraktivt syn på naturvitenskapelig kunnskap - et mer positivt bilde av naturvitenskap, slik vi formidler den til våre elever. Denne teorien inviterer oss til å presentere vitenskapens teori og praksis (teknologien) som et i høyeste grad menneskelig foretakende: et dristig (og meget vellykket) prosjekt, som hjelper oss til å forstå og beherske en stor del av den verden vi lever i - med det todelte mål å gi oss alle et bedre materielt liv, og klargjøre vår egen posisjon og rolle i verden!

Ja vel - og hva så da: hvordan skal dette undervises i praksis? La oss sammenlikne med den situasjon vi finner i andre fag/disipliner, spesielt innenfor humaniora og samfunnsvitenskapene. Her er det allment anerkjent at enhver elev må konstruere sin egen forståelse av stoffet! Det finnes ingen "riktig" måte å forstå/tolke litteratur (eller bildende kunst, eller musikk) på; heller ikke finnes det noen "sann" beskrivelse av (historiske eller nærværende) personer, eller av prosesser og fenomener i samfunnslivet. Det finnes ulike beskrivelser - modeller, forklaringsmåter, innfallsvinkler - og eleven står i prinsippet fritt til å velge den eller de som tiltaler ham/henne mest. Og disse beskrivelsene osv. undervises da ikke som "sannheter" som skal læres av eleven, men mer som "historier" som kan belyse det materiale som behandles. Slik kan man si at disse fagene (humaniora og samfunnsvitenskaper) i utgangspunktet står for et radikal-konstruktivistisk kunnskapssyn - eller, sagt på en annen måte, en relativistisk epistemologi.

Naturvitenskapen er faktisk alene (blant "vitenskapene", i vid forstand) om å forfekte en realistisk epistemologi - et kunnskapssyn der det gjelder å komme frem til den "endelige sannhet", og så dosere denne for elevene, med krav om å bli trodd på at "slik er det bare"! Kanskje bør vi revidere denne strategien, og begynne å fortelle i stedet - formidle til våre elever den spennende historien om hvordan mennesker har skapt naturvitenskapen..?

For å oppsummere: Jeg foreslår at man i naturfagenes didaktikk vier oppmerksomhet, ikke bare til det faglige innholdet, men også til det kunnskapssynet som formidles til elevene. Jeg hevder at den naturvitenskapelige epistemologien som ligger til grunn for vår undervisning er et spørsmål 
om personlig tro eller preferanse - og dermed ikke diktert av en "objektiv virkelighet" uavhengig av vår persepsjon. Og jeg antyder at en radikal-konstruktivistisk epistemologi, der man formidler et relativistisk kunnskapssyn, kan gi en bedre strategi for undervisningen av naturvitenskapsfag.

\section{REFERANSER}

Alters, B.J. (1997). 'Whose Nature of Science', Journal of Research in Science Teaching, 34, 39-55.

Bickhard, M.H. (1997). 'Constructivism and Relativisms: a Shopper's Guide', Science \& Education, 6(1-2), 43-53.

Foerster, H.v. \& Glasersfeld, E.v. (1999) Wie wir uns erfinden, Carl-Auer-Systeme Verlag, Heidelberg.

Geelan, D. (1997). 'Epistemological Anarchy and the Many Forms of Constructivism', Science \& Education, 6(1-2), 15-2.

Gentner, D. \& Gentner, D.R. (1983). 'Flowing waters of teeming crowds: mental models of electricity', in D. Gentner \& A.Stevens (eds.), Mental models, Hillsdale, NJ: Erlbaum.

Glasersfeld, E.v. (1978). 'Radical constructivism and Piaget's concept of knowledge', in F. B. Murray (ed.), The Impact of Piagetian Theory, Baltimore, University Park Press, pp.109-122.

Glasersfeld, E.v. (1984). 'An introduction to radical constructivism', in P.Watzlawick (ed.), The Invented Reality, New York, Norton, pp.17-40.

Glasersfeld, E.v. (1989). 'Constructivism in education', in T. Husen \& T.N. Postlethwaite (eds.), The International Encyclopedia of Education, Suppl. Vol.1, London/New York, Plenum Press, pp.162-163.

Glasersfeld, E.v. (ed.) (1991). Radical Constructivism in Mathematics Education, Kluwer Academic Publishers.

Glasersfeld, E.v. (1992). 'A constructivist view of learning and teaching', in R. Duit, F. Goldberg \& H. Niedderer (eds.), Research in Physics Learning. Theoretical Issues and Empirical Studies, Bremen, IPN, pp.29-39.

Glasersfeld, E.v. (1995). Radical Constructivism: A Way of Knowing and Learning, The Falmer Press.

Grandy, R.E. (1997). 'Constructivisms and Objectivity: Disentangling Metaphysics from Pedagogy', Science \& Education, 6(1-2), 43-53.

Hardy, M.D. \& Taylor, P.C. (1997). 'Von Glasersfeld's Radical Constructivism: a Critical Review', Science \& Education, 6(1-2), 135-150 .

Horgan, J. (1996). The End of Science, Addison-Wesley, New York.

Jenkins, E. (1997). 'Scientific and Technological Literacy for School Science: What can we learn from research and other evidence?', i S. Sjøberg \& E. Kallerud (eds.), Science, Technology and Citizenship, NIFU report (ISBN 82-7218-370-6).

Katz, A.N. (ed.) (1998). Figurative Language and Thought, Oxford University Press, New York

Larochelle, M., Bednarz, N. \& Garrison, J.(1998). Constructivism and Education, Cambridge Univ. Press.

Matthews, P. (1997). 'Problems with Piagetian Constructivism', Science \& Education, 6(1-2), 105-119.

Nola, R. (1997). 'Constructivism in science and science education', Science \& Education, 6(1-2), 55-83.

Ogborn, J. (1997). 'Constructivist Metaphors of Learning Science', Science \& Education, 6(1-2), 121-133

Phillips, D.C. (2000). Constructivism in Education, Univ. of Chicago Press, Chicago.

Quale, A. (2002). The role of metaphor in scientific epistemology, from a constructivist perspective: consequences for science education ', artikkel kommer i Science \& Education, 11. 
Sjøberg, S. (1997). 'Scientific Literacy and School Science', S. Sjøberg \& E. Kallerud (eds.), Science, Technology and Citizenship, NIFU report (ISBN 82-7218-370-6).

Sjøberg, S. (1998). Naturfag som Allmenndannelse, Ad Notam Gyldendal.

Sjøberg, S.(2000). Science and Scientist: the SAS study, Acta Didactica 1/2000, ISSN 1502-2013

Skinner, B.F. (1974). About Behaviorism, New York, Alfred A. Knopf.

Weinberg, S. (1993). Dreams of a Final Theory, New York, Random House.

Wittgenstein, L. (1921). Tractatus Logico-Philosophicus (norsk oversettelse), Gyldendal 1999. 